\title{
O AVANÇO NA DEFESA PROFISSIONAL
}

\author{
ADVANCES IN PROFESSIONAL DEFENSE
}

José Wazen da Rocha, TCBC - RJ

Há vários anos, principalmente após o advento do Código de Defesa do Consumidor, têm crescido as ações indenizatórias contra médicos, hospitais, laboratórios e entidades afins. Esse fenômeno, que traz em seu bojo uma série de questões jurídicas graves, tem gerado um desequilíbrio muito grande entre as partes envolvidas: pacientes, médicos e estabelecimentos prestadores de serviços de saúde.

Atento às ações indenizatórias, o mercado securitário vem lançando produtos que possuem o apelo de devolver a paz aos profissionais. São os chamados seguros de responsabilidade civil ou seguros de má prática, cópias do que vem sendo ofertado nos EUA, sem muito sucesso. Na classe médica, já é pacífico o entendimento de que a contratação do seguro não é a saída para a atual crise. Muito pelo contrário, a existência de um "pagador" estimula ainda mais as ações.

O erro médico tem sido alvo de várias demandas no Judiciário, uma vez que vem se constatando uma gama de vulnerabilidades em relação aos serviços prestados pelos médicos. Cada vez mais, os médicos devem se preocupar com a qualidade do atendimento e com a possível ocorrência de erros. O número crescente de processos judiciais contra médicos mostra que várias questões precisam ser analisadas e debatidas, no sentido de se encontrar medidas preventivas para lidar com os problemas.

A contratação da Banca A. Couto \& Advogados Associados, especialista em responsabilidade civil médica, como consultora jurídica do Colégio Brasileiro de Cirurgiões, mostra a nossa preocupação em oferecer a proteção e a defesa exigida pelos tempos atuais de Código de Defesa do Consumidor e do novo Código Civil. Entre os serviços a serem prestados pela Banca, estão os de consultoria, como os "primeiros socorros", sem ônus para os nossos membros, os quais, se assim o desejarem, poderão contratar os serviços da A. Couto; de assessoria jurídica para o CBC; e institucionais, com a realização de palestras e cursos.

Além de não advogarem para supostas vítimas de erro médico, os membros da Banca têm vários livros publicados na área de responsabilidade civil médica e hospitalar, criaram o Curso de Perícia Judicial para médicos e trabalharam para a fundação do IBRAMEP - Instituto Brasileiro de Médicos Peritos, hoje uma realidade. AA. Couto \& Advogados Associados já responde pela consultoria jurídica de várias entidades médicas e participa de uma União Nacional de Bancas, que defende médicos e hospitais em todo o país.

Ainda como parte do trabalho, a A. Couto \& Advogados Associados vai publicar artigos numa coluna fixa no Boletim Informativo do CBC, que vão abordar vários temas em responsabilidade civil médica. E, durante o XXV Congresso Brasileiro de Cirurgia, que acontecerá de 6 a 10 de julho, em Porto Alegre, a Banca vai realizar um julgamento simulado, apresentando um caso real, já julgado pelo Judiciário, para a discussão com os cirurgiões.

O Diretor de Defesa Profissional do CBC, Savino Gasparini Neto, já vem desenvolvendo um importante trabalho em defesa dos cirurgiões e pelo fortalecimento da especialidade, que agora será complementado pela atuação da A. Couto \& Advogados Associados. Neste momento, é de suma importância a adoção de medidas preventivas, a fim de resguardar a nossa imagem e o nosso patrimônio, obtidos através de muita dedicação e sacrifício. 